\title{
Homer's Ogygia: An Imaginary or a Historiography?
}

\begin{abstract}
By John Vella*
Epic poetry and legends are thought to be imaginary. Studies and science show that they may have a basis in history, yet the study of places-names - toponomy supported by a multi-disciplinary approach provides sufficient tangible evidence as to enable the tracing of unwritten historic events and the description of forgotten contexts. In this paper, the researcher will conduct an analysis of Homer's Ogygia, its character Calypso, and the events mentioned in the text. These factors provide enough details to classify and transform the perception of an imaginary story into a fact-based historic account - an early form of historiography - set on the island of Gozo-Malta.
\end{abstract}

\section{Introduction}

The author's earlier research has argued that toponyms and associated legends backed by tangible evidence are silent witnesses to an unwritten history. ${ }^{1}$ This study departs from imaginaries instigated by ancient Greek epic poetry and a toponym.

Homer's Odyssey is the earliest written reference to the Maltese Islands. For centuries, the Iliad and its narrative of the aftermath of the Trojan War were considered fictional, but archaeology has proven otherwise. Though epic poetry has led to contrasting discussions, this study hopes to inspire historians and historiographers to revolutionise the interpretation of historic imaginary intangibles. The study provides a paradigm for the inclusion of both tangible and intangible factors in the construction of a more realistic narrative of the remote past.

\section{Toponym Definitions}

The term toponym is not restricted to the lexicographic definition as "a place name, especially one derived from a topographical feature". ${ }^{2}$ The author expands toponymy to include place-names derived from practices, functions, persons and historic events, rather than solely geographical or

\footnotetext{
* PhD Student, Mediterranean Institute, University of Malta, Malta.

1. John Vella, "Thalassic imaginaries: silent witnesses to (an) unwritten history" (Paper presented at the Thalassic Imaginaries Conference, Mediterranean Institute, University of Malta, Malta, 23-24 January 2015).

2. Angus Stevenson and Maurice Waite (Eds), Concise Oxford English Dictionary Luxury edition, $12^{\text {th }}$ edition (Oxford University Press, Oxford, 2011), 1521, see "toponym". 
topographical features. ${ }^{3}$ The study of unwritten historic events can be inspired by what is considered as imaginaries born out of toponyms, tied to legend, folksong, habits and other long-standing evidence, and analysed through a multi-perspective approach. ${ }^{4}$

\section{Methodology}

The multi-disciplinary approach applied to toponyms ${ }^{5}$ attempts to identify different sources which together lead to a common occurence. Evidence is searched among both tangible and intangible sources, such as epic poetry, legend, toponyms, language, written documents, pictography and astronomy.

The approach in this study is to analyse two toponyms: "Ggantija" as an item of intangible evidence used by the local community and "Ogygia" as an intangible record in Homer's Greek epic poetry. A third written source that is analysed in this study is the Bible, as a historic record of Eastern Mediterranean cultures contemporary to the events recounted in the Odyssey.

Homer's epic poetry was considered as a record that preserved ancient local legends, communicated orally but undocumented before. Toponyms and legends preserve memories and local histories, but they have lost the connection between them and have survived independently and disjointedly. While local legend and toponyms provide tangible and intangible forms of evidence, epic poetry provides written tangible evidence as a form of ancient historiography. When these intangibles and tangibles are brought together, they provide for and become themselves "tangible evidence" of history, or better, of an unwritten history.

\section{Analysis}

\section{Dating and Contextualisation of Events}

Homer wrote his epics around $762 \mathrm{BC}( \pm 50$ years $) .{ }^{6}$ Scientific research and archaeology maintain that the Odyssey took place around 1188-1178 $\mathrm{BCE}^{7}$ while the Iliad (Trojan War) occurred between the $13^{\text {th }}$ and $12^{\text {th }}$

3. In this study the author followed the definition proposed by Joshua Nash, "Insular Toponymies: Pristine place-naming on Norfolk Island, South Pacific and Dudley Peninsula, Kangaroo Island, South Australia" (PhD diss., University of Adelaide, Australia, 2011), 77-78.

4. Vella, "Thalassic imaginaries: silent witnesses to (an) unwritten history".

5. Ibid.

6. Joel N. Shurkin, "Genomes and language provide clues on the origin of Homer's classic". Inside Science American Institute of Physics, accessed June 1, 2015, http://bit.ly/ 2dWUPAm.

7. Constantino Baikouzis and Marcelo O. Magnasco, "Is an eclipse described in the Odyssey?" Proceedings of the National Academy of Sciences, PNAS, Astronomy, 105, no. 26 (2008), 8823-8828. 
century BC. ${ }^{8}$ Their age preceded the rise of ancient Greek civilisation but witnessed the spread of Phoenician trading colonies. Based on astronomical indications within the text, Ulysses's stay on Ogygia dates to around 2300 BC. ${ }^{9}$ During this particular period $(2300<1178$ BC) the Maltese Islands and southern Sicily were transitioning from the Bronze Age to Classical Antiquity. Until c. $2000 \mathrm{BC}$, the Maltese islands formed one land mass, including the islet of Filfla and another island that is now submerged. ${ }^{10}$ Little is known about the islands at that age.

This study maintains that in the Iliad, Homer documented an unwritten history which had happened at least three centuries before his birth and which was part of an oral tradition for generations. ${ }^{11}$ Among writers of early maritime cultures, contact with the outside world inspired awe and stories were retold to the younger generations. Maritime adventures, irrespective of whether they had a good or a bad ending, were more likely to become oral traditions than everyday events.

\section{Epic Poetry: Homer's Odyssey and Gozo}

Similarities are noted in the length and fate of the voyages of both Ulysses and St Paul. ${ }^{12}$ Both end shipwrecked on the northern coast of the Maltese Islands, and both see no land during their voyage. Documented experiences of navigators of antiquity, classical or early mediaeval times may be of invaluable aid to researchers in ancient sea routes.

Ulysses's southbound voyage through the Straits of Messina led him to his shipwreck off Gozo. He was the only survivor. ${ }^{13}$ Sailing close to the north-eastern Gozitan coast, Ulysses attempted to disembark at a visibly safe landing-place, presumably close to what is now the bay of Ramla 1Hamra [lit. Red Bay]. One should remember that in those far-off years the coastline was extended further offshore in areas that are now covered by the sea. Calypso's Cave was formerly hidden by large trees ${ }^{14}$ but now deforested overlooks this bay. Homer's description of the Gozitan landscape

8. Shurkin, "Genomes and language provide clues on the origin of Homer's classic"; Altschuler et al., "Linguistic evidence supports date for Homeric epics," Bioessays, Insights and Perspectives, Ideas and Speculations 35, no. 5(2013): 417-420.

9. Wood and Wood, Homer's Secret Odyssey, 88.

10. Kurt Lambeck et al. "Glacial rebound and sea-level change: solutions for oceanvolume fluctuations, ice sheets and mantel rheology" Research School of Earth Sciences, The Australian National University, http://bit.ly/2daHiRx; Aaron Micallef et al. "The submerged paleolandscape of the Maltese Islands: Morphology, evolution and relation to Quaternary environmental change," Marine Geology 335, no. 1(2013): 129-147.

11. Altschuler et al., "Linguistic evidence supports date for Homeric epics", 419; Wood and Wood, Homer's Secret Odyssey, 9.

12. KJBV, accessed June 29, 2015. Acts Ch. 27.

13. A.T. Murray, (trans.) Homer - The Odyssey in two volumes (Cambridge, MA., Harvard University Press, London, William Heinemann, Ltd., 1919). See Book V, Lines 243-245, 249-250; Wood and Wood, Homer's Secret Odyssey, 22-23.

14. Murray, Homer - The Odyssey, Book V: 63-64. 
depicts a wooded ${ }^{15}$ and fertile land with an abundance of honey ${ }^{16}$, good food and fruit ${ }^{17}$ : a description which conforms with later descriptions of Gozo.

Homer's description of Ogygia is found in the Odyssey. The local

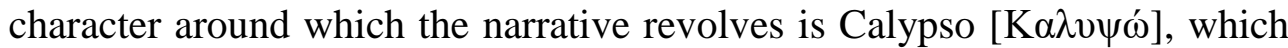
in Greek literally translates into "coverage, treatment" or "she that conceals". ${ }^{18}$ Calypso may not have been her actual name or what she was locally called, but a name attributed to her Odysseian role, a name intended to define her social function on the island. Homer describes her as a goddess, ${ }^{19}$ an immortal and a nymph, ${ }^{20}$ but an analysis of the narrative reveals that she was no common woman in ancient Gozitan-Maltese society. Apart from her natural beauty, her attire, behaviour and actions indicate that she occupied a high position of authority which demanded respect at both civil and spiritual levels. She was skilled, had a good relationship with the community and was respected even in other areas of Gozo-Malta. We may think of her as having been a sovereign and a high priestess acting as the head of a then matriarchal society.

The name "Calypso" itself, as adopted by Homer, Ulysses or those who experienced the Odyssey themselves, is indicative of a person whose role in ancient society was that of "one who conceals". Her function within the spiritual realm may have been that of an oracle, one who kept concealing from Ulysses what she knew through her practices. She protected and

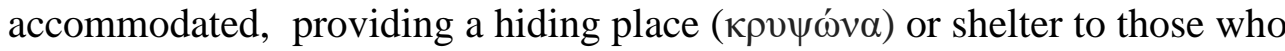
needed it. The characteristic of hospitality, rather than hostility, is commonly attributed to the Mediterranean communities, as was the case with the mythical island of Ogygia or Gozo-Malta. ${ }^{21}$

Homer mentions Ogygia as the island of Calypso, ${ }^{22}$ but gives no direct description of the island's community. He speaks about trees and abundant vegetation, honey and fruit present on the island, which indicates the presence of an industrious rural community. Homer presents Calypso as a

15. Murray, Homer - The Odyssey, Book V: 238-240, 241-242.

16. Murray, Homer - The Odyssey, Book V: 93, 199.

17. Murray, Homer - The Odyssey, Book V: 69, 95, 166-167, 196-197.

18. Henry George Liddell and Robert Scott, A Greek-English Lexicon, (Oxford: Clarendon Press, 1996), see "Calypso" entry; Roger D. Woodard (ed), The Cambridge Companion to Greek Mythology (New York: Cambridge University Press, 2007), 72-73.

19. Murray, Homer - The Odyssey, Book V: lines 78, 85, 97, 116, 159, 173, 178, 180, 192, 202, 215, 242, 246, 258 and 276.

20. Murray, Homer - The Odyssey, Book V, lines 6, 14, 30, 57, 149, 153, 196, and 230.

21. Mohamed Tozy, "The Mediterranean between popular Imaginary and Realities". The fact that Ulysses spent eight years on the Island of Ogygia is indicative of a relationship which grew and developed into something more than an acquaintanceship. Certainly in this time-span Ulysses got to know much more about Calypso's astronomical practices and roles in her society. This therefore clears many of the doubts about the toponym given to and mentioned in narratives about the island of Gozo-Malta at that time and what happened in that insular society.

22. Ogygia is mentioned in the original text in the genitive case [ $\Omega \gamma v \gamma$ in $\varsigma$ - of Ogygia] and in the accusative case [' $\Omega \gamma v \gamma$ í $v$ - Ogygia]; Murray, Homer - The Odyssey, Book I:Line 85, IV: 172, VII: 244, VII: 254, VII: 448, XXIII:333; From here on all references made to Murray, trans., are also found in Capps, Page and Rouse, Homer - The Odyssey Vol. I. 
hard-working loom-weaver. ${ }^{23}$ The weaving of Ulysses's new clothes ${ }^{24}$ and sails $^{25}$ are evidence of the presence of loom-weavers on the Island. ${ }^{26}$ Loomweaving, especially of a sacking-type cloth called "xoqqa", is still synonymous with Gozo.

The practice of weaving may be considered as a pastime adopted by Calypso, but useful to meet necessities and for trading. Homer recounts that Calypso used to sing rhymes while weaving in her cave. ${ }^{27}$ This reminds us of ghana, the ancient genre of folk-singing, a traditional pastime practised by Gozitan and Maltese women while they were busy making the traditional bizzilla (bobbin lacework) or doing some other task. Both ghana and bizzilla have survived to the present day, albeit now practised mainly for touristic purposes. Homer notes that Calypso felt alone on the island. ${ }^{28}$ She must have felt isolated if the population was sparse and few people visited Ogygia. As Gozo-Malta gained strategic importance in terms of maritime traffic, it is not excluded that in cases of misfortune or necessity mariners sought help or refuge on the island.

It is therefore reasonable to assume that communities on Gozo-Malta would develop maritime services and facilities. The availability of wood fit for shipbuilding is mentioned. Calypso took Ulysses to fetch wood for the building of his vessel. Above all, Calypso brought Ulysses a bronze axe sharpened on both sides to cut down trees and to plane the wood; a polished adze; augers to bore the wood; a tool for hammering pegs and mortices; woven sails; and all that was necessary to build and complete a sea-vessel fit for a long voyage. ${ }^{29}$ The availability of specific tools and paraphernalia provides evidence of a community which could build sea-vessels and provide them with the necessary maritime items.

Homer's narrative in this case presents more detail than in the case of $\mathrm{St}$ Paul's departure from Malta in 61AD, when the vessel was provided and loaded with necessaria for the voyage. ${ }^{30}$ It is not improbable that Calypso knew well the trades and crafts available on the island. Her social standing as a person of authority facilitated access to that. Coupled with Calypso's own knowledge of the locality, eight years on a small island was sufficient time for Ulysses to get to know the island and its inhabitants.

Homer's extract saying that Calypso took Ulysses to the island's borders means that she took him to the southernmost part of the island to procure dried wood and find crafts persons who could help him construct the vessel he required. Another possibility is that Ulysses met people who navigated on routes to and from his own land to the island and planned his departure with them. Though the epic states that Ulysses sailed away alone

23. Murray, Homer - The Odyssey,, Book V: lines 61-62.

24. Murray, Homer - The Odyssey,, Book V: lines 167-170, 263-264 and 321.

25. Murray, Homer - The Odyssey,, Book V: lines 258-259.

26. Wood and Wood, 88.

27. Murray, Homer - The Odyssey, Book V: line 61.

28. Murray, Homer - The Odyssey, Book V: lines 206-213.

29. Murray, Homer - The Odyssey, Book V: lines 234-246.

30. Vella, "Thalassic imaginaries: silent witnesses to (an) unwritten history"; KJBV, Acts, 28:10-11. 
- a way of presenting him as a hero - it is quite improbable, as at the start of the Archaic Period ( $8^{\text {th }}$ century BC), ancient Greek communities started navigating in the western Mediterranean for trade and establishing colonies along the southern Sicilian coast. However the wicker fence along the sheer strake $^{31}$ suggests that Ulysses built his ship on the design of Phoenician cargo-ships. This feature indicates that at the time of the Odyssey, the island was already significantly Phoenician. ${ }^{32}$ Though details about life on Gozo became first known thanks to the documents written in the Roman era, it was in the works of later authors or historiographers, such as Agius de Soldanis, that specific details became known.

\section{Gozitan Historiography: Agius de Soldanis}

Agius de Soldanis sustains that both Calypso and Ogygia are references related to Gozo, but was reluctant to discuss this topic further. ${ }^{33}$ He justifies his stance by stating that his objective dealt with history and not imaginary epic poetry. Yet, for the entire pages he speaks about giants who inhabited Gozo. ${ }^{34} \mathrm{He}$ attempts to define and interpret "giants" in the Gozitan context, but he acknowledges the difficulty of having lack of evidence. He begins by revealing the information he had collected and what others had said about these "giants". Agius de Soldanis, in accordance with other authors whom he did not identify, states that "giants" is not a reference to huge persons but to real people who were very strong and hardy.

Taking his cue from the biblical narrative, Agius de Soldanis compares the legend of the giants on Gozo to the "nephilim", a race which existed before the great flood, but who in the post-deluge years settled on islands, among which was Gozo. Subsequently he corroborates Aristotle's argument that these "giants" were the Cyclops who inhabited caves and underground spaces, and built towers with large stones. Agius de Soldanis attributes megalithic structures to these legendary "giants" and mentions remains that include Ix-Xaghra tal-Ghażżenin [the uncultivated land of the lazy], known as Ggantija [of the Giant], which at that time was referred to as the "Torre dei Giganti" [Giants' Tower]. ${ }^{35}$ Contemporarily, a similar reference to the legend about giants comes from Gravius ${ }^{36}$ who observed two megalithic

31. Murray, Homer - The Odyssey, Book V: lines 256-257.

32. Though previous studies maintain that the Maltese islands became Phoenician after 900BC the Odyssey indicates otherwise and is evidence of Phoenician presence from at least the $12^{\text {th }}$ century BC.

33. Farrugia, Mons. Guzepp, (trans) Giovanni Pietro Francesco Agius de Soldanis, Ghawdex bil-Grajja tieghu (Malta: Stamperija tal-Gvern, 1936), 14-15. Agius De Soldanis was writing in 1736-1739.

34. Farrugia, (trans.) Giovanni Pietro Francesco Agius de Soldanis, Ghawdex bilGrajja tiegћu, 52-55.

35. The denomination of "giants' tower" is also reported in Antonio Annetto Caruana, Report on the Phoenician and Roman Antiquities in the Group of the Islands of Malta (Malta: Government Printing Press, 1862), 7.

36. J. G., Gravius, Thesaurus antiquitatum et historiarum Siliciae, quo contenitur... Vol. 15 (Belgium:.Publ. Petrus Vander Aa, University of Ghent, 1725), 89-90. Gravius as 
remains himself, a site that "evidentissima vestigial habitationis gigantum" [bears evidence that giants inhabited the area] - the first at Xewkija and a second at "El Eeijun" [il-Ghejjun: the natural water springs], ${ }^{37}$ a reference to Ggantija (Xaghra) that also denotes the presence of natural springs.

To strengthen his argument about giants inhabiting Gozo, Agius de Soldanis mentions the recovery of a huge canine ${ }^{38}$ and skeleton. ${ }^{39}$ Stories about giants abound among ancient Mediterranean cultures. However, rather than speaking about giants, this study intends to provide a historic basis to the Ogygia toponym from a multi-disciplinary perspective.

\section{Discussion}

From the Intangible Imaginary to Tangible Evidence

The discovery of Troy provided the imaginary Iliad with tangible historical evidence. Homer's epics, being the oldest known Greek literary sources, are therefore not an imaginary. They are a record of early ancient Greek cultures and their contacts with the Mediterranean world. Greek seapeople were then sailing west to set up trading colonies in the central Mediterranean. In an age of exploration and discovery, maritime experiences were well-preserved as oral history and passed on to younger generations.

It is not excluded that some imaginary or enhancement to laud the perceived heroes, gods and other characters could have been added; but the historic basis and basics could not be changed so much as to distort or change the authenticity and the message behind the story. Therefore the name Calypso, based on Ulysses's post-shipwreck experience on Ogygia, is authentic.

the author's surname is also spelt in Latin as Gravæus. Gravius was translating from Giovanni Francesco Abela, Della Descrittione di Malta Isola nel Mare Siciliano con le sue antichita, ed altre notitie... (Malta: Publ. Buonamici per Paolo Bonacota, 1647).

37. Abela, Della Descrittione di Malta Isola nel Mare Siciliano con le sue antichita, ed altre notitie, 119, refers to it as "El Eeyun".

38. Though Agius de Soldanis (in Farrugia, transl. Giovanni Pietro Francesco Agius

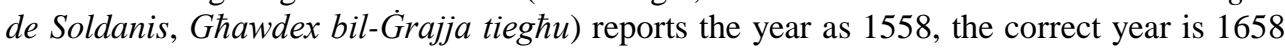
as reported by in Caruana, Report on the Phoenician and Roman Antiquities in the Group of the Islands of Malta, 3). He states that the huge canine found was donated to Pope Alexander III by Grand Master De Redin.

39. The skeleton was found on Manoel Island (Gżira, Malta) during the excavation for the foundations of Fort Manoel (1723) and to which reference is made in Abela, Della Descrittione di Malta Isola nel Mare Siciliano con le sue antichita, ed altre notitie ... A similar discovery of a tall, well-built human skeleton was described to me by some workers who were engaged on excavations for the San Ġwann t'Ghuxa housing estate in Bormla behind the small church of St. John the Alms-giver (Elemosinaire) in the mid-1970s. It was next to other Punic tombs, adorned with pottery items and jewellery among which a golden octagonal ring (shown to me in 2008) which had Egyptian hieroglyphs and Punic letters engraved on it. The tombs were destroyed by orders of the then Minister for Public Works who had no respect for cultural heritage. 


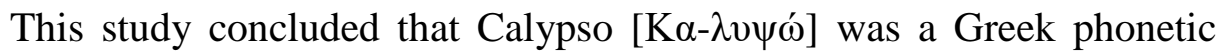
transliteration. Based on the root consonants $l-b-s$ of the Maltese verb libes (to dress), K $\alpha-\lambda v \psi \omega ́$ is a transliteration of the vocative case $\hbar a$ ilbsu (dress up!) which phonetically became $\hbar$ a il-ps-oo. ${ }^{40}$ Therefore the phrase by which Calypso ordered naked shipwrecked Ulysses to put on clothes, became a convenient nickname which Ulysses himself used to narrate about Calypso. Calypso, as named by Ulysses or the elderly folk from whom Homer must have heard the story, may have been then the chief priestess of the island community.

Archaeology and megalithic remains in the proximity of Calypso's cave are evidence of an ancient thriving community and a centre of activity for the island's community prior to the recorded history. The presence of the Neolithic and Bronze Age remains on high ground is unusually large on Gozo when compared to its size and probable population at that time. It is the toponym of a megalithic structure at Xaghra which gives most weight to the theory that the island of Ogygia is Gozo-Malta. ${ }^{41}$

\section{From Giants to the "Giant": Toponym and Legend}

The megalithic structure popularly termed as a "temple" is Ggantija. Its function is connected with seasonal cycles and equinoxes. ${ }^{42}$ There are no surviving legends or memories which explain specifically the meaning of the toponym. Legend has it that Ġgantija was built by a giantess named Sansuna. She was so strong that while she carried the megaliths on her head from $\mathrm{Ta} \dot{ }^{\prime} \dot{\mathrm{C}} \mathrm{enc}^{43}$ to Xaghra, she ate broad beans and suckled her child. On the northern side of Xaghra, there is a huge stone propped at an angle called "Il-Giebla ta' Sansuna" [the Stone of Sansuna], ${ }^{44}$ assumed by some to be the remains of a Bronze Age dolmen.

40. The letter $\hbar$ in Maltese sounds like $h$ in hot. It was also a voiceless glottal fricative in ancient Greek dialect.

41. The proximity of the two sites in Xaghra (a name that means "plateau" or "open land") is interesting. A walk from Calypso's cave to Ġgantija covers a distance of only $2.5 \mathrm{kms}$ and can be covered in about 30 minutes. Such a walk must have been shorter in the days of the Odyssey as there were no built-up areas. During my explorations in Xaghra I discovered numerous megaliths and megalithic structures, mostly unrecorded and unprotected. Though most lie in rural areas, others were damaged, destroyed or removed to make way for regular urban development in the village.

42. John Vella, Malta and Prehistoric Times, Diss. Pontificial University of St. Thomas Aquinas, 1995.

43. Ta' Cencं is a high plateau over the southwest cliffs of Gozo. It bears remains from the Neolithic and the Bronze Age such as early megalithic structures and dolmens. It is considered to have been the burial ground for Neolithic and Bronze Age village chiefs.

44. Translation: "The stone of Sansuna". Sansuna, is the female name for Samson in Maltese, a name which has died out in Malta and Gozo. The biblical Samson, pronounced "shemshun" in Hebrew, means "sun", "Sun Child" or "Bright Sun", which once again may indicate a connection to the seasonal cycles. This may even connect the Sansuna figure to the toponym of Xemxija that lies in the north of Malta. If the biblical name dates to around 1118-1078 BC, the use of a similar name across the Mediterranean in the same age is possible, and it may even connect to the woman in the Gozitan legend. Information about 
The existence of "giants" on ancient Gozo-Malta could be termed as an imaginary, but legends and archaeological evidence of huge, strong, longstatured humans in the past cannot be denied by modern science and some still inhabit Gozo. ${ }^{45}$ Though the study excludes any discourse about genetics, it may inspire further scientific research on early Gozitan communities.

All in all, communities have lost memory of the ancient connections between the Ġgantija megalithic structure and the astronomical. The imposition of religious taboos on the astronomical ${ }^{46}$ led the locals to forget about ancient practices and links between the megalithic structure and the Giant in the sky. All this led to the birth of legends about a giantess in the distant past.

\section{Giants in Greek Mythology}

Greek mythology abounds with references to the existence of giants or people of huge stature. Among these was Orion, a hunter who supposedly walked on water. ${ }^{47}$ In this study the "Giant" being referred to is Orion, depicted in the constellation named after him by Greek mythology. This raises questions. Was it Greek mythology that created the Ggantija toponym on Gozo-Malta? Or was it Greek epic poetry that was actually influenced by what navigators narrated after their journeys to Gozo-Malta in the $2^{\text {nd }}$ millennium BC?

\section{Doubts Created the Imaginary}

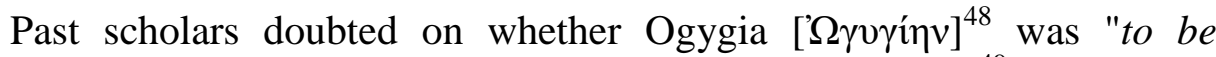
regarded as the name of Calypso's island or as an epithet." ${ }^{49}$ Hesoid and Callimachus used óyv́rıv [ogygian] ${ }^{50}$ as an adjective to evoke antiquity:

Samson and dates The Chronology of Judges solved!, accessed May 29, 2015, http://bit.ly/ 2dX69wv.

45. In my frequent visits to Gozo, I have met many Gozitans of a stature reaching well over the height of six feet $(+1.88$ metres). Tall and well-built persons are mostly observed in the villages of Qala and Nadur.

46. By "astronomical" the author means the division of time and seasons, not the astrological interpretation. Religions imposed their own festivals to mark time and seasons.

47. TGM - Theoi E-Texts Library Homer. Odyssey Book V, accessed May 27, 2015. http://bit.ly/2dnEjuA.

48. Murray, Homer - The Odyssey, Book I: Line 85, IV: 172, VII: 244, VII: 254, VII: 448, XXIII:333, in Capps et al., see entry on "Ogygia".

49. Alfred Heubeck, Stephanie West and John Bryan Hainsworth, A Commentary on Homer's Odyssey, vol. I (Oxford: Clarendon Press, 1988), 85-86.; Pierre Chantraine, Dictionnaire etymologique de la langue grecque - Histoire des mots [Etymological dictionary of the Greek language - History of words] (Paris: Editions Klincksieck, 1977), 1297-1298.

50. M.L., West, Hesiod: Theogony (Oxford: Oxford University Press 1966), 43-45. Hesoid lived between 730 and 705BC; Christophe Cusset, "Other Poetic Voices in 
something prehistoric, ancient, primordial or from the beginning of time. ${ }^{51}$ The etymology of ' $\Omega$ ýzlos [Ogygian, Ogýgios] was also said to mean primeval, primal, from the earliest ages ${ }^{52}$ or from the dawn of time ${ }^{53}$. While Homer used Ogygia as a placename, he articulated the waters of Styx in Calypso's expression to define something very ancient, ${ }^{54}$. Consequently Hesoid referred to the waters of Styx as something very ancient with the word ogygian ${ }^{55}$.

The adjective "ogygian" was therefore reminiscent of an ancient prehistoric place memorised through ancient Greek oral lore. Whatever was very old was "most honorable" and demanded great respect. ${ }^{56}$ Later authors used the adjective with a similar meaning, ${ }^{57}$ yet "ogygian" was also used to define things bulky and large ${ }^{58}$ and gigantic. ${ }^{59}$ This definition supported the author's association of Ogygia to the Gozitan toponym $\dot{G}$ gantija [of the Giant]: still related to Malta's oldest megalithic structure.

Callimachus", in Brill's Companion to Callimachus, ed. Acosta-Hughes, Benjamin, Luigi Lehnus and Susan Stephens (Leiden - Boston, Brill, 2011), 459.

51. Evelyn White G. Hugh (trans.). Hesiod - The Homeric Hymns and Homerica (Cambridge, MA., Harvard University Press, Cambridge, London: William Heinemann Ltd., 1914), lines 805-806. http://bit.ly/2drzgps; Glenn W. Most (Ed) (Tans.), Hesoid Theogony Works and Days Testimonia (Cambridge, Massachusettes: Harvard University Press, 2006), 68-69.

52. Liddell and Scott, A Greek-English Lexicon, see entry for ' $\Omega \gamma v ́ \gamma 10 \varsigma$ : A. Ogygian, of or from Ogyges, a mythical king of Attica: hence generally, "primeval, primal,[...]from earliest ages $[. .$.$] 2. gigantic [...]".$

53. Richard Jebb, (Ed.) The Philoctetes of Sophocles (Cambridge, Cambridge University Press, 1898), line 142. Sophocles lived between c.497 and 405BC.

54. Murray, Homer - The Odyssey, Book V: line 185.

55. Evelyn White, Hugh G. (transl.), lines 805-806; see explanation and translations of

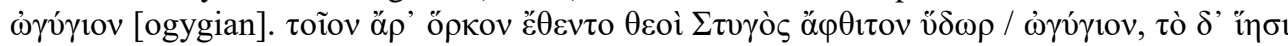

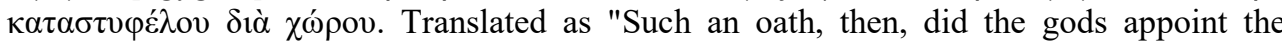
eternal and primeval water of Styx to be: and it spouts through a rugged place." See also: http://bit.ly/2cZC0e6, translation by Tyrrell on http://bit.ly/2dG5zEs.

56. Most, Hesoid - Theogony Works and Days Testimonia, 244-247.

57. Among these were (1) Aeschylus from Gela, Sicily (c.525-455BC) in (a) Herbert Weir Smyth, transl., Aeschylus. Aeschylus, with an English translation in two volumes. 1.Seven Against Thebes (Cambridge, Mass., Harvard University Press, 1926), line 321; (b) ibid. 1.Persians, line 37; (c) ibid. 1. Persians, line 975; (d) ibid. 2. Eumenides, line 1036; (d) Pindarus (Greek, c.522-443BC), in Boeckh, August, edit., Pindarus Lyricus - Pindari Opera quae supersunt, (Leipzig: Ioann. August. Gottlob Weigel, 1811), Pindarus Lyricus. in Nemean 6.44; (e) Storr, F., transl. Sophocles. Sophocles. Vol 1: Oedipus the king. Oedipus at Colonus. Antigone (London: William Heinemann Ltd., 1912), line 1770; (f) Jebb, Sophocles, line 142; (g) Hirschig, W. A, Heliodorus Scriptor Eroticus, Erotici Scriptores (Paris: Didot Edition, 1856), 10.25.

58. Alexander MacBean and Samuel Johnson, A Dictionary of Ancient Geography: Explaining the Local Appellations in Sacred, Grecian, and Roman History... (London: G. Robinson \& T. Cadell, 1773), see entries for "Ogygia": "things bulky and large are called Ogygia," accessed September 30, 2014, http://bit.ly/2drEBg9.

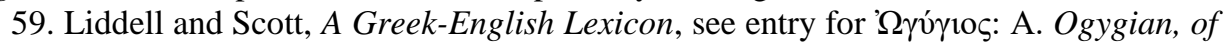
or from Ogyges, [...] 2. gigantic [...]; Hirschig, Heliodorus Scriptor Eroticus, Erotici Scriptores, 10.25. Author's note: A similar adjective is colossal which derived from the Colossus of Rhodes is subsequently used to determine something huge or even gigantic. 


\section{Origins of the Legend}

The legend of Ogygia and its connection especially with Gaudos (Gozo, Malta) started less than three centuries after Homer, when Herodotus stated that Ogygia formed part of the Maltese archipelago. ${ }^{60}$ Followed by Euhemerus $^{61}$, Callimachus ${ }^{62}$ and later authors as Diodorus Siculus ${ }^{63}$, the Ogygia-Gozo connection persisted through authors as the medieval Gozitan historian Agius De Soldanis ${ }^{64}$ and modern day academics. ${ }^{65}$ Since Ogygia was no longer similar to what Odysseian age seafarers experienced, the content was deemed imaginary and therefore a legend.

\section{Geographic Confusion}

Eight centuries after Homer, Strabo placed Ogygia further west into the Atlantic Ocean. He criticized harshly Callimachus ${ }^{66}$ and Polybius ${ }^{67}$ for attributing Calypso's Island to Gaudos (Gozo). Strabo perceived matters

60. Mifsud, Anton, Simon Mifsud, Chris Agius Sultana and Charles Savona-Ventura, Malta. Echoes of Plato's Island (Malta: The Prehistoric Society, 2000), 18, accessed http://bit.ly/2cZCjFR; Herodotus was a Greek from Halicarnassus in modern day Turkey, who lived between c.484 and c.420BC.

61. Mifsud et al., Malta. Echoes of Plato's Island (Malta: The Prehistoric Society, 2000); Page, T.E., E. Capps, W.H.D. Rouse, L.A. Post and E. H. Warmington, (Eds.), The Geography of Strabo, H.L. Jones, (trans) (London: William Heinemann Ltd., 1916), 528 (q.v. Euhemerus). Euhemerus was a Greek from Messina, Sicily who lived between 330 and 260BC.

62. Annette Harder, (Ed.), Callimachus Aetia: Introduction, Text, Translation, and Commentary vol: I (Oxford: Oxford University Press, 2012), see entry for Frag. 470: 145 146; Rudolf Pfeiffer, Callimachus Fragmenta vol I (Oxford: Clarendon Press, 1949), fr. 470; Page et al., I.2.37 : 162-163, 526 (q.v. Callimachus). Callimachus was a Greek native of Cyrene, Libya who lived between 310/305 and 240BC. He was a librarian at the ancient library of Alexandria which was burnt down by the Romans in 48BC. It is widely known even today that political interests and knowledge conflict. What if such knowledge remained available and sustained by authors during the Roman dominance of the Mediterranean? Strabo may have been led on these lines through his education in Rome and other pro-Roman authors followed suit not to be censored or silenced [Author's observation].

63. Immanel Bekker, Ludwig Dindorf and Friedrich Vogel, (Eds.). Diodorus Siculus Diodori Bibliotheca Historica, vol 1-2, Book V, (Publ. B. G. Teubner. Leipzig, 18881890), ch. 12, sections 1-4 Diodorus Siculus, was a Greek born in Sicily and lived between 90 and $21 \mathrm{BC}$.

64. Farrugia, (trans.) Giovanni Pietro Francesco Agius de Soldanis, Ghawdex bilGrajja tiegћu, Agius De Soldanis lived between 1712 and 1770.

65. Mifsud et al., Malta. Echoes of Plato's Island. Accessed September 12, 2015. http://bit.ly/2cZEF7I.

66. H.C. Hamilton, and W. Falconer, (trans.) Strabo, Geography (London: H.G. Bohn, 1854), book VII, ch. 3; A. Meineke (Ed.) Strabo - Geographica (Leipzig: Publ. Teubner,

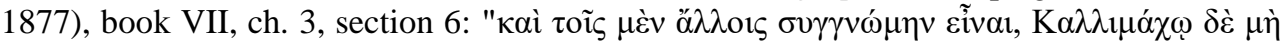

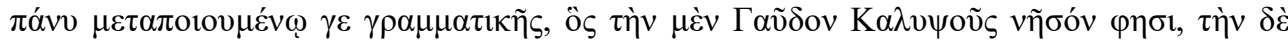

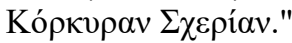

67. Page et al., The Geography of Strabo, 1.2.18: Polybius was a Greek historian who lived in Greece between c. 200 and c.118BC. 
from the Mare Internum ${ }^{68}$ perspective of his time not from the ancient Greek perspective which considered the east Mediterranean basin as their sea. Strabo's placement of the islands was heavily criticised by modern scholars. ${ }^{69}$ Homer stated that Ogygia was at the navel or centre point of the sea $^{70}$ because in Odyssean and Homerian times it was between the Greek dominated sea (east Mediterranean) and the sea of Atlas (west Mediterranean). ${ }^{71}$

\section{Confusion of Toponyms}

The positioning of Ogygia near either Italy or Crete ${ }^{72}$ resulted from the mid-first century BC following Strabo. Mela recorded Gaudos (Ghawdex) as Gaulos ${ }^{73}$. Pliny complicated matters when he referred to Cauda ${ }^{74}$ (Crete) as Gaudos and misled later authors. Ptolemy called Gozo as Glauconis Insula $^{75}$. Attempts to transliterate placenames into classical Greek or Latin

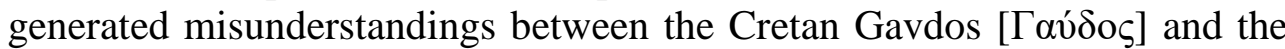
Gaudos attributed to Gozo. ${ }^{76}$ Chaos continued with the mediaeval Venetians who referred to the Cretan Gavdos as Godzo. ${ }^{77}$ Through these inconsistencies many authors were misled.

68. Strabo lived between c.64BC and 23AD. The Mare Internum comprising the east and west Mediterranean was the Roman Mare Nostrum.

69. Jurgen Spanuth, Atlantis: The Mystery Unravelled (London: Arco, 1956).

70. Capps et al. Homer - The Odyssey Vol. I, Book I: 50.

71. Harry Thurston Peck, Harpers Dictionary of Classical Antiquities. New York: Harper and Brothers, 1898: see "Ogygia" entry; William Smith, Dictionary of Greek and Roman Geography, in two volumes, llustrated by numerous engravings on wood (London: Walton and Maberly, 1854), see "OGY'GIA" entry. Note: The sea of Atlas or the west Mediterranean was at that time dominated by the Phoenicians (later Carthaginians) whom the Greeks called Atlantioi (q.v. C.H. Oldfather, (trans.), Diodorus Siculus - Diodorus Siculus. Library of History (books iii - viii, Vol. 303 and 340 (Cambridge, MA.: Harvard University Press, 1935), 3. 56. 1 - 57. 8.

72. Finkelberg, Margalit edit., The Homer Encyclopedia (West Sussex: WileyBlackwell, 2011), 594.

73. Frank E. Romer (Ed.). Pomponius Mela's Description of the World (U.S.A.: The University of Michigan Press, 2001), book 2: 120 (vide page 101); see also Map reconstruction on Konrad Miller, "Orbis habitabilis ad mentem Pomponii Melae", Mappaemundi, Heft VI. "Rekonstruierte Karten", Tafel 7, (1898). Mela’s work was dated to around 43BC.

74. KJBV, Acts 27:16. Pliny lived between 23 and 79AD.

75. Carolus Fridericus Augustus Nobbe, edit., Claudii Ptolemaei Geographia (Lipsiae: Caroli Tauchnitii, 1843), lib. IV, Cap. 3.4: 246 (line 13). Ptolemy lived between c.100 and 170AD.

76. John Vella, How Ghawdex (Gozo) and Malta got their name (forthcoming paper, Mediterranean Studies Association, Conference, Malta, 2017, (2016).

77. MacBean and Johnson, A Dictionary of Ancient Geography: Explaining the Local Appellations in Sacred, Grecian, and Roman History..., see entries for "Gaudos" and "Gaulos". http://bit.ly/2dnSFLg. In Vella, How Ghawdex (Gozo) and Malta got their name, the author explains how Gaudos was the real appellation for Ghawdex (Gozo) and how it came about and why, which makes it totally different from the Gavdos of Crete which the mediaeval Venetians later called Godso. 
A fundamental reason for uncertainty among authors ${ }^{78}$ arose from a lack of knowledge of both Maltese language and toponymy. The exclusion of these two prevented them from reaching similar conclusions where both etymology and meaning of Ogygia are still preserved in the "Ggantija"

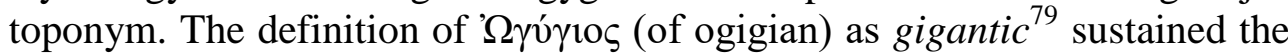
Odysseian transliteration of Ggantija [of the Giant] into Ogygia.

Since the conclusion was reached by this research, similar conclusions were absent from previous studies. The author relied on a multidisciplinary approach of toponymy, language, archaeology and history. Another omission of previous scholars was the change in sea-level between the Odysseian age $\left(2^{\text {nd }}\right.$ millennium BC) and the $8^{\text {th }}$ century BC when Homer recorded oral history. To strengthen the argument that Ogygia was Calypso's Island or the ancient Gozo-Malta Island, reliance went further than tradition, legend and local lore. ${ }^{80}$

\section{The Toponym and Language}

In Maltese, the word $\dot{G}$ gantija is the genitive or possessive form of "Ggant" (giant) and is translated fluidly into "of the Giant", "that pertaining to the Giant", "the Giant's own" or "belonging to the Giant". This meaning leads to the astronomical connection evident in the Ggantija structure which points to the Orion constellation. Greek mythology shares the myth that Orion was a giant. We may easily assume therefore that Homer or other oral narrators were influenced by Ulysses's Gozitan experience, and Homer's Ogygia was a literal translation of "Ġgantija".

If Calypso or the Odysseian Gozitano-Maltese indicated that the megalithic structure was connected to the rising of the "Giant" Orion over the horizon, ${ }^{81}$ they or Calypso herself said it in their own language and vocabulary. Homer, Ulysses or whoever actually travelled to Gozo-Malta used oral methods to report what they saw. Odyssey in ancient Greek must be a literal translation of the toponym as indicated and interpreted by the islanders themselves. In doing so, the toponym $\dot{G}$ gantija - "belonging to the Giant" - was literally preserved unaltered, but disconnected from the memory of the name by which the island was called in antiquity. ${ }^{82}$ On the other hand, it was Homer who translated it in their terms, or else it was

78. Chantraine, Dictionnaire etymologique de la langue grecque - Histoire des mots, 1297-1298; Heubeck, West and Hainsworth, A Commentary on Homer's Odyssey, vol. I, $85-86$.

79. Liddell and Scott, A Greek-English Lexicon, see entry for ' $\Omega \gamma v ́ \gamma 1 o \zeta ;$ and, Hirschig, Heliodorus Scriptor Eroticus, Erotici Scriptores, 10.25.

80. Farrugia, (trans.) Giovanni Pietro Francesco Agius de Soldanis, Ghawdex bilGrajja tiegћu, 14-15.

81. John Vella, Malta and Prehistoric Times, 1995.

82. During medieval times many Gozitan communities, especially the young and the strong, children, men and women, ended up abducted and taken into slavery by raiding Ottoman fleets. This could have certainly negatively impacted on the oral transmission of knowledge from one generation to another. 
narrated to Homer in this way. The original name eventually changed linguistically or dialectically into $\Omega \gamma v y i \alpha$, which is derived from $o$ y $\imath \imath \alpha$ or $o$ $\gamma \iota \gamma \alpha$ which translates into "the giant". This could be the way Homer or the oral narrators he recorded described Gozo-Malta in his days. The Giant or

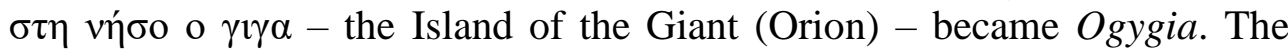
present writer searched for similar practices among Mediterranean people who regarded the Orion constellation of importance in their culture. The most commonly known cultures are those of the Eastern Mediterranean which, thanks to the Bible, became known worldwide.

\section{The Toponym and the Bible}

In Biblical texts, the Giant constellation is mentioned by name at least three times: twice in Job and once in Amos. ${ }^{83}$ The Book of Amos, written between 760-753 BC, coincides with the writing of the Homeric epics. The Book of Job, dated between 1280-1270 BC, claimed to be older than any other Biblical book, ${ }^{84}$ narrates events concurrent with the Odysseian events. More than an imaginary narrative, both Biblical texts and Homeric epics qualify as precursors of historiography or public memory records, preserving oral traditions transmitted over at least four centuries. Within them, the transmission of names and toponyms is rarely subjected to change, even though characters and places may be enhanced by the imaginary. Eventually the recording of place-names like Ogygia, the ancient island of Gozo-Malta, may even lead us to think about other toponyms on the Maltese islands and elsewhere.

\section{Pictography and Astronomy}

Nineteenth century etchings, drawings and lithographs of the Ggantija megalithic structure did not provide information on the toponyms, except by calling it Torre dei Giganti or Tour des Geants on Calypso's Island (Figures 1-4). ${ }^{85}$ While art could only provide the visual, more information on the connection of Ggantija with the astronomical cycles could only come through other sources. As people observed and became aware of celestial movements, they constructed permanent markers to record their cycles. Proof of the importance of Orion's movements comes through in Job's text, and proof that Ġgantija was named after the Giant's

83. KJBV, Job 9: 9 and 38: 31; and KJBV, Amos 5: 8.

84. G. L., Bartholomew, Dating the Book of Job, Accessed May 29, 2015, http://bit.ly/2dVqHBZr, 37.

85. Among them are etchings: Louis-Eustache Audot, L'Italie, la Sicile, les îles Éoliennes, l'île d'Elbe, la Sardaigne, Malte, l'île de Calypso, etc [Italy, Sicily, the Aeolian Islands, the island of Elba, Sardinia, Malta, the island of Calypso, etc] Vol. 3 (Paris: Publ. Audot Père, 1835); and L[ouis] Mazzara, Temple dit des Geants decouvert dans l'ile Calipso aujourd'hui Gozo, pres de Malte [Temple Ante-Diluvien said to be of the Giants discovered in Calipso's island, today Gozo, near Malta ] (Paris: Publ. Engelmann, 1827). 
constellation $^{86}$ comes through in the Maltese version of the Bible which refers to Orion as "il-Ggant".

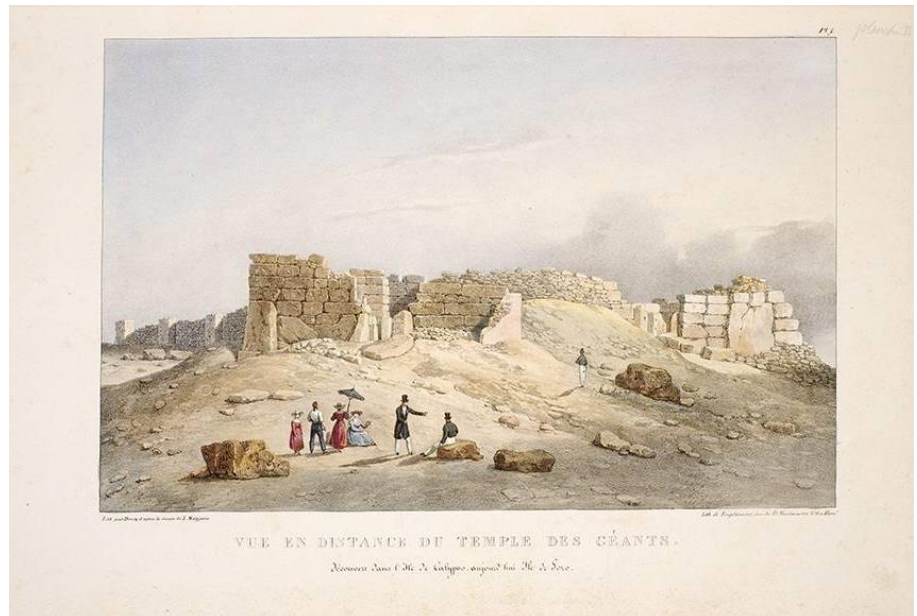

Figure 1. View of the Temple of Giants on the Island of Calypso, Gozo, from a Distance

Source: Mazzara (1827) Coloured Plate 2. Vue en distance du Temple des Geants découvert dans l'isle de Calypso, aujourd'hui Ile de Gozo.

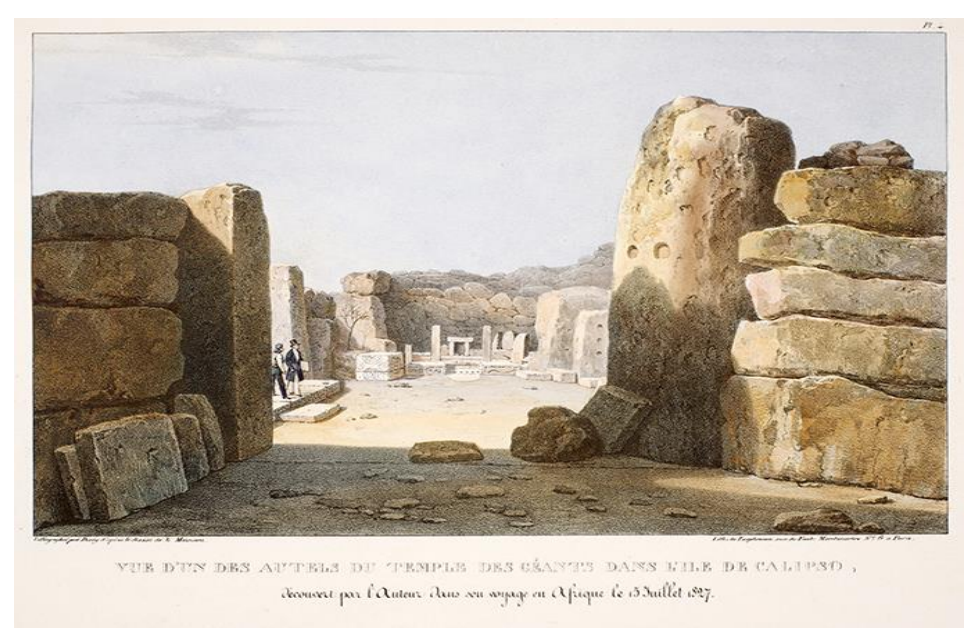

Figure 2. View of One of the Altars inside the Temple in 1827

Source: Mazzara, 1827, Coloured Plate 5. Vue d'un des autels du Temple des Geants dans l'isle de Calipso découvert par l'Auteur dans son voyage en Afrique le 15 Juillet 1827.

86. Vella, Malta and Prehistoric Times, 59; with reference to KJBV, Job, 38:31-33. 87. Vella, John, Malta and Prehistoric Times, 87; KJBV, Job, 38: 31-32. 


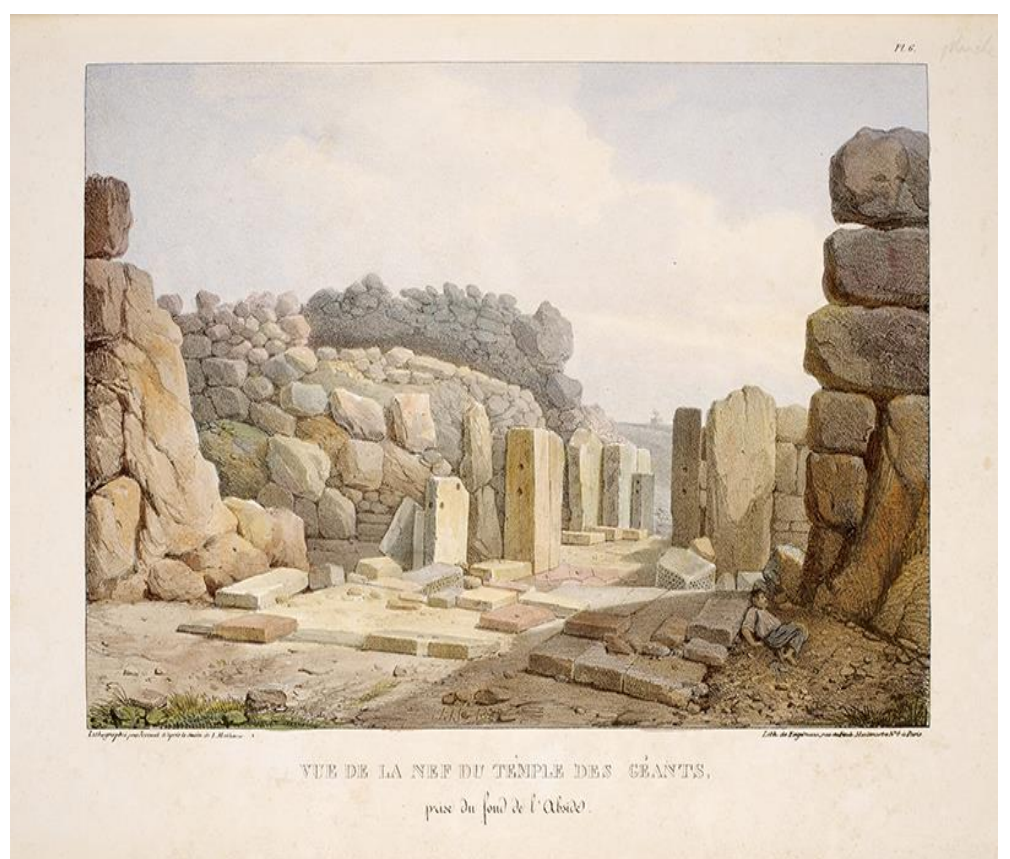

Figure 3. A Nave of the Temple of Giants from the Apse's End

Source: Mazzara, 1827, Coloured Plate 7. Vue de la Nef du Temple des Geants prise du fond de l'Abside.

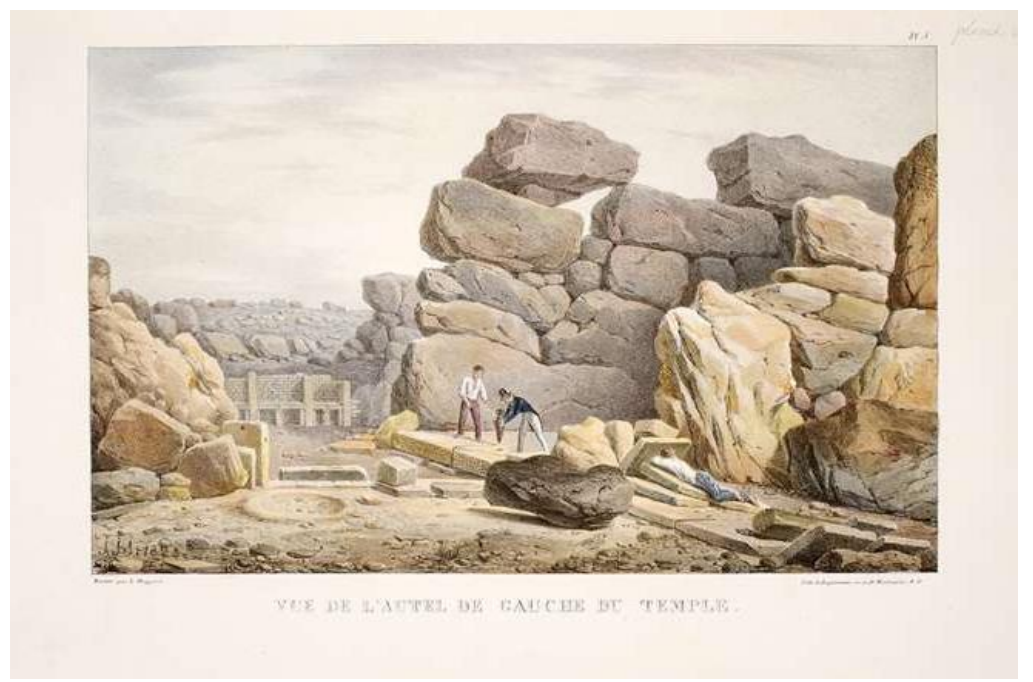

Figure 4. View of the Altar on the Left of the Temple

Source: Mazzara, 1827, Coloured Plate 6. Vue de l'Autel de gauche du Temple.

Confirmation of Homer's knowledge of astronomy emerges in studies and interpretations of the Odyssey. ${ }^{88}$ Orion's constellation features among the night-sky signs regarded with importance by early skilled navigators. ${ }^{89}$ Some authors maintain that Homer's description of Calypso's cave, her loom, her weaving and the four rivulets are figures of speech intended to describe astronomical signs visible in the night sky. ${ }^{90}$ Yet the literal is still

88. Wood and Wood, Homer's Secret Odyssey, 11-12.

89. Wood and Wood, Homer's Secret Odyssey, 34, 87-88, 90-92, 98, 141, 149, 215.

90. Wood and Wood, Homer's Secret Odyssey. 86-87. 
visible in the environs of Calypso's Cave (Figure 5), namely, Xaghra's natural springs. ${ }^{91}$ Even if the literal is excluded, except for the astronomical observation, the cave environs were placed in a location high enough to obtain full unobstructed visibility of the night-sky.

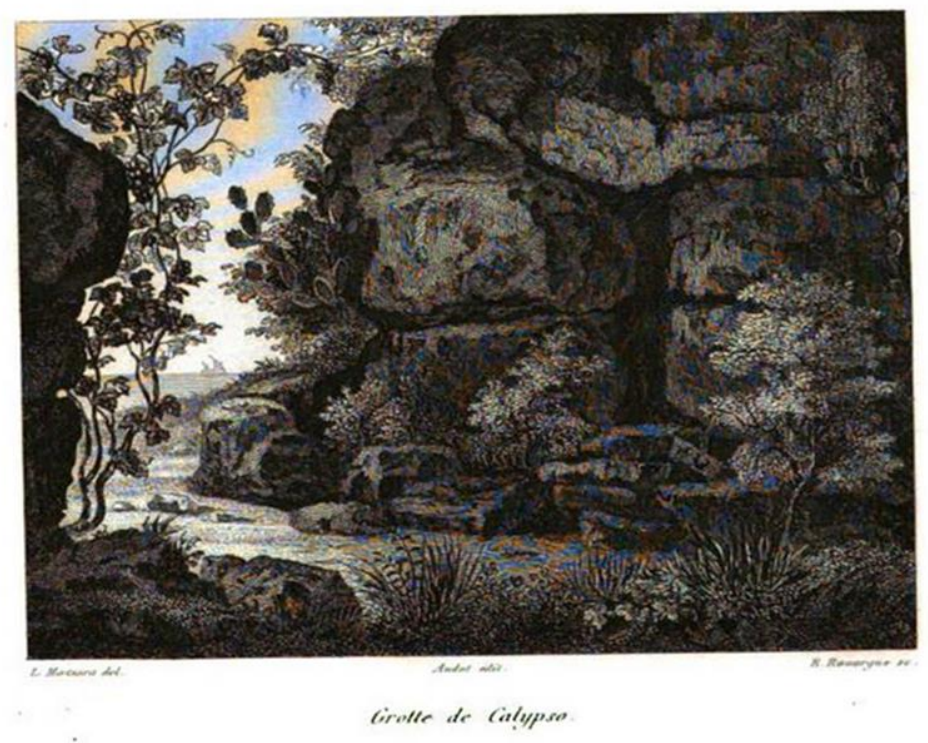

Figure 5. Calypso's Cave, Xaghra, Gozo

Source: Audot, 1835, Grotte de Calypso - Stahlstich v. Mazzara/Rouargue, 1835, Steel engraving. Plate 117: 370.

Homer's epic narrative is proof of Calypso's extraordinary knowledge of astronomy. She instructed Ulysses on how to navigate and find directions on his voyage back home..$^{92}$ She gave "advice on how to use the Pleiades, Boötes, the Bear and Orion to navigate his craft." ${ }^{93}$ Calypso instructed Ulysses to keep an eye on Orion. ${ }^{94}$ This helped Ulysses or the oral narrators to further connect the Giant constellation to the island, and hence the "Ogygia" toponym. Ulysses sailed eastwards when he departed from Ogygia, ${ }^{95}$ on a route which Mediterranean navigators have taken since at least classical antiquity.

We may therefore conclude that the ancient island of Gozo-Malta was known as "Il-Gżira tal-Ǵgant" or "The Island of the Giant (Orion)", documented in Homer's Ogygia and memorised in the Ġgantija toponym. The toponym and its connection to the astronomical figure were lost due to

91. Referred to earlier as El Eeijun [il-Ghejjun] by Gravius, Thesaurus antiquitatum et historiarum Siliciae, quo contenitur... vol. 15, 89-90, with reference to Abela, Della Descrittione di Malta Isola nel Mare Siciliano con le sue antichita, ed altre notitie. ... The Maltese word "ghajn' means a natural fresh-water spring and "ghejjun" is the plural form.

92. Wood and Wood, Homer's Secret Odyssey, 34, 87-88.

93. Murray, Homer - The Odyssey, book V: lines 269-277; Wood and Wood, Homer's Secret Odyssey, 34.

94. Wood and Wood, Homer's Secret Odyssey, 90-92.

95. Frank Beetham, Beginning Greek with Homer (U.S.A.: Publ. Bloomsbury Academic, University of Michigan, 1998), iii. 
various natural, man-made and exclusionary factors imposed by time and history itself. Among others, we may attribute the loss to a consequence of forgetfulness or the diminishing dependence on astronomy when it came to farming and navigation. This may also have been due to religious taboos concerning popular reliance on astronomy.

\section{Conclusion}

Earlier researchers maintained that Homer's works, his vocabulary and "even fictional texts can preserve traces of history." ${ }^{96}$ Eventually the evidence cited above provides sufficient proof which transforms the Odyssey from a fictional into a real account of historical events. At the same time, it qualifies Homer not only as an epic poet but as a pioneer historian and recorder of Mediterranean oral history.

The conclusions that have emerged from this study are that Homer's Ogygia is not an imaginary but a reference to and a record of ancient GozoMalta. The Ggantija toponym is witness to an ancient history when Gozo more than the rest of the Ogygian island was known for its connection with the Giant's (Orion's) seasonal cycles and astronomical observation. Calypso is representative of the community, their practices and their crafts on the then Gozo-Malta island. The description of the landscape increases our knowledge of the natural environment on the island during the Odysseian age.

Furthermore, the study is proof that toponymy can be used for linguistic and scientific research. It inspires further research into a history which was either unrecorded or deliberately obliterated. If supported by the analysis of toponyms and related evidence from other disciplines (even though they may contain elements of the imaginary), epic poetry and legend, commonly perceived as fictional or imaginary in nature, become narratives which gain credibility as records of historic events and figures.

Toponyms in legends and in epic poetry may, in the absence of written historical records, serve as a mnemonic of events which actually happened long ago and which human memory may have forgotten about. Toponymy and other elements traced in legends and epic poetry may provide scientific evidence which can lead to a revisiting of historiography. A transdisciplinary approach to the study of history bears better results than a mono-disciplinary approach.

The conclusions that have been reached open a wider discourse on toponyms attributed to ancient sites, in particular on the Maltese islands. They encourage further studies into whether toponyms given to megalithic and other sites reveal more of an unrecorded history than archaeologists and historiographers themselves. This paper demonstrates that historiography

96. Altschuler et al. "Linguistic evidence supports date for Homeric epics", 419. 
demands a multi-disciplinary approach $^{97}$ if it aims to provide a more authentic record of remote historical events.

\section{Acknowledgement}

My thanks go to my family for the support given and patience shown during my research.

\section{Bibliography}

Abela, Giovanni Francesco. Della Descrittione di Malta Isola nel Mare Siciliano con le sue antichita, ed altre notitie [Description of Malta Island in the Sicilian Sea with its antiquities, and other information]. Malta: Publ. Buonamici per Paolo Bonacota, 1647.

Altschuler, Eric Lewin, Andreea S. Calude, Andrew Meade and Mark Pagel. "Linguistic evidence supports date for Homeric epics." Bioessays, Insights and Perspectives, Ideas and Speculations 35, no. 5(2013): 417-420.

Baikouzis, Constantino and Marcelo O. Magnasco. "Is an eclipse described in the Odyssey?" Proceedings of the National Academy of Sciences, PNAS, Astronomy, July 1, 2008, 105, No. 26, 8823-8828. Accessed September 29, 2014. http://bit.ly/2cOAE7L.

Bartholomew G. L., Dating the Book of Job. Accessed May 29, 2015. http://bit.ly/ $2 \mathrm{dVqHBZ}$.

Beetham, Frank. Beginning Greek with Homer. U.S.A.: Publ. Bloomsbury Academic, University of Michigan, 1998.

Bekker, Immanel, Ludwig Dindorf and Friedrich Vogel (Eds.). Diodorus Siculus Diodori Bibliotheca Historica, vol 1-2. Leipzig: Publ. B. G. Teubner., 18881890.

Boeckh, August (Ed.). Pindarus Lyricus - Pindari Opera quae supersunt, Leipzig: Ioann. August. Gottlob Weigel, 1811.

Capps, E., Page, T.E. and W.H.D. Rouse (Eds.). Homer - The Odyssey vol. I . A.T. Murray (Trans.). London: William Heinemann, 1927.

Caruana, Antonio Annetto. Report on the Phoenician and Roman Antiquities in the Group of the Islands of Malta. Malta: Government Printing Press, 1862.

Chantraine, Pierre. Dictionnaire etymologique de la langue grecque - Histoire des mots [Etymological dictionary of the Greek language - History of words]. Paris: Editions Klincksieck, 1977.

Cusset, Christophe. "Other Poetic Voices in Callimachus." In Brill's Companion to Callimachus, edited by Benjamin Acosta-Hughes, Lehnus Luigi and Susan Stephens. Leiden - Boston, Brill, 2011.

Farrugia, Mons. Ġużepp (transl.) Giovanni Pietro Francesco Agius de Soldanis,

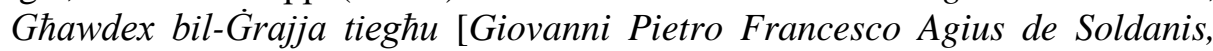
Gozo with its history]. Malta: Stamperija tal-Gvern, 1936.

97. The methodological approach is the one used by the author in this paper, in Vella (2015) and in other research studies on toponyms by the same author. It may be defined as "the process of analysing and setting out from the intangible to research for supportive tangible evidence which complements and sustains the veracity of perceived imaginaries and legends". 
Finkelberg, Margalit (Ed.). The Homer Encyclopedia. West Sussex: WileyBlackwell, 2011.

Gravius, J. G. Thesaurus antiquitatum et historiarum Siliciae, quo contenitur... Vol. 15. Belgium:.Publ. Petrus Vander Aa, University of Ghent, 1725.

Hamilton, H.C. and Falconer, W., (Trans.). Strabo of Geography, book VII. London: H.G. Bohn, 1854.

Harder, Annette (Ed.) Callimachus Aetia: Introduction, Text, Translation, and Commentary vol I. Oxford: Oxford University Press, 2012.

Heubeck, Alfred, West Stephanie, and John Bryan Hainsworth. A Commentary on Homer's Odyssey, vol. I. Oxford: Clarendon Press, 1988.

Hirschig, W. A. Heliodorus Scriptor Eroticus, Erotici Scriptores. Paris: Didot Edition, 1856.

Hugh, Evelyn White G. (trans.). Hesiod - The Homeric Hymns and Homerica. Cambridge, MA., Harvard University Press, Cambridge, London: William Heinemann Ltd., 1914. http://bit.ly/2drzgps.

Jebb, Richard (Ed.). The Philoctetes of Sophocles, Cambridge, Cambridge University Press, 1898.

KJBV - King James Bible Version online. Accessed June 29, 2015. http://bit.ly/1 mql8gm.

Lambeck, Kurt, Tony Purcell, Jason Zhao and Andrea Dutton. "Glacial rebound and sea-level change: solutions for ocean-volume fluctuations, ice sheets and mantel rheology." Research School of Earth Sciences, The Australian National University, http://bit.ly/2daHiRx.

Liddell, Henry George, and Robert Scott. A Greek-English Lexicon, revised and augmented throughout by Sir Henry Stuart Jones with the assistance of Roderick McKenzie. Oxford: Clarendon Press, 1996, 9th edition with a Revised Supplement.

MacBean, Alexander and Samuel Johnson. A Dictionary of Ancient Geography: Explaining the Local Appellations in Sacred, Grecian, and Roman History. London: G. Robinson \& T. Cadell, 1773.

Meineke, A. (Ed.). Strabo - Geographica. Leipzig: Publ. Teubner, 1877.

Micallef, Aaron, Federica Foglini, Timothy Le Bas, Lorenzo Angeletti, Vittorio Maselli, Alessandro Pasuto and Marco Taviani. "The submerged paleolandscape of the Maltese Islands: Morphology, evolution and relation to Quaternary environmental change." Marine Geology 335, no. 1(2013): 129147. http://dx.doi.org/10.1016/j.margeo.2012.10.017 .

Mifsud, Anton, Simon Mifsud, Chris Agius Sultana and Charles Savona-Ventura, Malta. Echoes of Plato's Island. Malta: The Prehistoric Society, 2000.

Miller, Konrad. "Orbis habitabilis ad mentem Pomponii Melae." Mappaemundi, Heft VI. "Rekonstruierte Karten", Tafel 7, 1898.

Most, Glenn W., (Ed) (Trans.). Hesoid - Theogony Works and Days Testimonia. Cambridge, Massachusettes: Harvard University Press, 2006.

Murray, A.T. (trans.) Homer - The Odyssey in two volumes. London, William Heinemann, Ltd., 1919. http://bit.ly/2drp1RX.

Nash, Joshua, "Insular Toponymies: Pristine place-naming on Norfolk Island, South Pacific and Dudley Peninsula, Kangaroo Island, South Australia". PhD diss, University of Adelaide, 2011.

Nobbe, Carolus Fridericus Augustus (Ed.). Claudii Ptolemaei Geographia. Lipsiae: Caroli Tauchnitii, 1843.

Oldfather, C.H., (Trans.). Diodorus Siculus - Diodorus Siculus. Library of History, (books iii - viii, vol. 303 and 340. Cambridge, MA.: Harvard University Press, 1935. 
Page, T.E., E. Capps, W.H.D. Rouse, L.A. Post and E. H. Warmington, (Eds.). The Geography of Strabo. H.L. Jones, (trans.). London: William Heinemann Ltd., 1916.

Peck, Harry Thurston, Harpers Dictionary of Classical Antiquities. New York: Harper and Brothers, 1898.

Pfeiffer, Rudolf. Callimachus Fragmenta vol I. Oxford: Clarendon Press, 1949.

Romer, Frank E. (Ed.). Pomponius Mela's Description of the World, U.S.A.: The University of Michigan Press, 2001.

Shurkin, Joel N."Genomes and language provide clues on the origin of Homer's classic". Inside Science, American Institute of Physics. Accessed June 1, 2015. http://bit.ly/2dWUPAm.

Smith, William. Dictionary of Greek and Roman Geography. London: Walton and Maberly, 1854.

Spanuth, Jurgen. Atlantis: The Mystery Unravelled. London: Arco, 1956.

Stevenson, Angus, and Maurice Waite (Eds). Concise Oxford English Dictionary Luxury edition, $12^{\text {th }}$ edition. Oxford: Oxford University Press, 2011.

Storr, F. (Trans.). Sophocles vol. 1. Oedipus the king. Oedipus at Colonus. Antigone. London: William Heinemann Ltd., 1912.

The Chronology of Judges solved!. Accessed May 29, 2015. http://bit.ly/2dX69wv.

TGM - Theoi E-Texts Library Homer. Odyssey Book V. Accessed May 27, 2015. http://bit.ly/2dnEjuA.

Tozy, Mohamed. "The Mediterranean between popular Imaginary and Realities." Accessed May 27, 2015. http://bit.ly/2doYvch.

Vella, John. Malta and Prehistoric Times. Diss. Pontificial University of St. Thomas Aquinas, 1995.

Vella, John. "Thalassic imaginaries: silent witnesses to (an) unwritten history." Paper presented at the Thalassic Imaginaries Conference, Mediterranean Institute, University of Malta, Malta, 23-24 January 2015.

Vella, John, How Ghawdex (Gozo) and Malta got their name. Forthcoming, paper prepared for the Mediterranean Studies Association, Conference, Valletta, Malta, 2017, (2016).

Weir Smyth, Herbert (transl.) Aeschylus. Aeschylus, with an English translation in two volumes. 1.Seven Against Thebes. Cambridge, Mass., Harvard University Press, and London: William Heinemann, Ltd., 1926.

West, M.L. Hesiod: Theogony. Oxford: Oxford University Press 1966.

Wood, Florence and Kenneth Wood, Homer's Secret Odyssey. Gloucestershire, UK: The History Press, 2014.

Woodard, Roger D., (Ed.). The Cambridge Companion to Greek Mythology. New York: Cambridge University Press, 2007.

\section{Image Sources}

Audot, Louis-Eustache. L'Italie, la Sicile, les îles Éoliennes, l'île d'Elbe, la Sardaigne, Malte, l'île de Calypso, etc [Italy, Sicily, the Aeolian Islands, the island of Elba, Sardinia, Malta, the island of Calypso, etc] Vol. 3. Paris : Publ. Audot Père, 1835.

Mazzara, L[ouis], Temple Ante-Diluvien dit des Geants decouvert dans l'ile Calipso aujourd'hui Gozo, près de Malte [Temple Ante-Diluvien said to be of the Giants discovered in Calipso's island, today Gozo, near Malta]. Paris: Publ. Engelmann, Montmartre, 1827. 
